\title{
Simmel and Mannheim on the Sociology of Philosophy, Historicism and Relativism ${ }^{1}$
}

\author{
Martin Kusch
}

\section{Introduction}

This paper identifies and evaluates some central relativistic and historicist themes in earlytwentieth-century German sociology of knowledge. The two main figures are Georg Simmel (1858-1918) and Karl Mannheim (1893-1947).

Concentrating on Simmel and Mannheim might seem surprising in a volume focussed on philosophical positions concerning relativism. Indeed, Simmel and Mannheim are today primarily remembered as amongst the most influential 'founding fathers' of the social sciences. It is important, however, to remember that the two men worked in an academic world in which the borders between philosophy and the social sciences were unclear and open (cf. Goodstein 2017). Moreover, Simmel never held a chair in sociology and did not think of himself as a sociologist. And both thinkers put forward ideas and theories that were recognized as philosophical and sociological by their contemporaries.

Neither 'relativism' nor 'historicism' had a precise and agreed-upon meaning in earlytwentieth-century debates. Still, put in very general terms, 'relativism' referred to the denial of truths that are universal, fixed, and independent of human psychology and cultures. 'Historicism' meant the idea that, to understand any phenomenon, one needs to understand its history. Obviously, these two ideas could be combined.

Simmel and Mannheim systematically reflected on the relationship between relativism and historicism. They were not the first to do so. Historical and philosophical theorizing about the status of history (as a field of study) had already highlighted the tensions between historical contingency and philosophical normativity. The novel element in Simmel and Mannheim was their efforts to bring these issues to bear on the philosophy of the social sciences in general, and the sociology of knowledge in particular.

In Simmel's and Mannheim's work relativism and historicism featured in at least three different ways. First, both developed and defended distinctive general claims about various kinds of "relativism". Second, in their historical case studies, Simmel and Mannheim made use of, what they regarded as, "relativistic" methodologies. And third, both Mannheim made the emergence of relativism and historicism a central topic for their sociological-

\footnotetext{
${ }^{1}$ Work on this paper was made possible by the ERC Advanced Grant Project (2014-2019):
} 
historical inquiries. Finally, to these three dimensions of relativism within Simmel's and Mannheim's writings, we can add a fourth that goes beyond: their writings triggered vigorous and extensive debates about relativism.

My overall evaluative thesis is that my early sociologists of knowledge were not fully successful in dealing with relativism. Simmel declared himself a relativist but it remains unclear what precisely his relativism amounted to. Mannheim had a clearer view of relativism but thought of it as something the sociology of knowledge had to avoid at all costs. But he hardly succeeded in his attempts to do so. Fortunately, in neither case did the lack of success regarding the philosophical handling of relativism weaken the quality and interest of the sociological-historical case studies.

\section{Simmel on Money and Philosophy}

A natural starting point for my investigation is Simmel's Philosophie des Geldes (1900/2004). I am here only considering its nascent sociology of philosophy, to wit, its attempts to identify parallels between philosophical ideas and economic practices or theorising. Simmel claims that such type of inquiry has been made possible by the "worldview" of "relativism" (142).

The central contrast running through the book is between modern and ancient/medieval interpretations of money. The ancient or medieval rendering amounted to a "materialist conception" (173): the value of money is the "substance" out which it is made (167). Moreover, influential thinkers, like Aquinas, insisted that money should not be traded or lent for interest (168). Closely related to this was the "just price doctrine", the idea of "a direct relationship between object and money-price" (125). As Simmel has it, the substance-value conception was "the appropriate theoretical expression of an actual sociological condition", and the conception fell apart when the condition disappeared (173). The condition in question was that people in ancient and medieval times valued "landed property" (234) and "an agrarian economy ... with few and hardly variable intermediaries" (235).

This rough sketch suffices for us to see how Simmel links the "materialist conception of money" to philosophy. He proposes that this conception was inseparable from - that is, both supported by and supportive of - the metaphysical topoi of fixed substances with essential or accidental properties; a static, eternal cosmos (168); a static social organization (234); and forms of philosophy focused on qualitative rather than quantitative categories (148). 
Turning from Antiquity and the Middle Ages to Modernity, Simmel insists that the modern, "transcendental", understanding of money radically broke with its predecessors. It was Adam Smith who first articulated the new "transcendental theory" (173). Most human relationships were now understood as relationships of exchange. Indeed, economic exchange was rendered the basic building block of society (99). Exchange was taken to be "as productive and value-creating as is prodution itself" (81). Simmel emphasises especially the ways in which the market mechanism turns numerous different subjective preferences into one objective value (i.e. the stable price) (75-76).

Simmel finds numerous parallels between key aspects of modern monetary reality or economic theorizing and philosophical reflection. Suffice it here to mention three. The first concerns "relativity": the economic value of each good is dependent upon - and thus relative to - the economic value of every other good. Money "symbolizes" such relativity (118). The relativity of money has its philosophical analogue in the emergence of various forms of relativism. The second parallel might be called the 'dual perspective point': on the one hand, money stands aside from, or opposite to, all goods that can be bought and sold with its help. But, on the other hand, for the moderns, money is also itself a good (119). In the philosophical domain this corresponds to a view of epistemic norms as both constitutive of space and time, and as empirical-psychological phenomena in spatiotemporally situated subjects (119), and a view of the ego as both transcendental and empirical (128). The third key link between modern money and philosophy concerns "condensation". For the modern thinkers money "condenses" the value of things (197). The philosophical counterparts of this idea vary: they include the notion of "laws of nature" as condensations of "endless particular cases" (303); the modern idea of the "state" that with the help of the civil service - functions as a condensation of political powers (197); and the conception of "objectivity" as condensed intersubjectivity (79).

\section{Simmel on Historicism and Relativism}

Simmel emphasizes repeatedly that the modern understanding of money goes together with philosophical relativism and historicism. This naturally invites the question how Simmel conceived of relativism and historicism. Simmel most influential intervention into the historicism debates - the Probleme der Geschichtsphilosophie (1892/1989) - discussed the "historical apriori". ${ }^{2}$ This is the idea that the historian invariably imputes mental states

\footnotetext{
${ }^{2}$ I am not suggesting that Simmel was the first to put forward this idea, but he developed it in exceptional detail.
} 
to historical actors, and that the selection of such states depends crucially on the personality and social background of the historian in question (304). Accordingly, Simmel rejects Leopold von Ranke's (1795-1886) demand according to which historians must "eliminate themselves" in order to understand the past (321). Moreover, Simmel takes his insight as confirmed by the fact that there is space for a sociological study of historical scholarship: it is usually possible to identify the social position of the historians from their texts (325). In some places Simmel accepts the natural implication that all historical work is invariably perspectival (328).

Simmel's "historical apriori" resonated with many other authors at the time. One obvious case in point is Theodor Lessing's (1872-1933) Geschichte als Sinngebung des Sinnlosen (1921/2012). The title sums up the content perfectly. Ernst Troeltsch's (18651923) Der Historismus und seine Probleme (1922/1977) attributes to Simmel the intention to overcome "suffocating 'historical realism"' (578). But Troeltsch is not satisfied with Simmel's reflections: "To Dilthey's relativism of values he [i.e. Simmel] adds a shaky relativism concerning the relationship between the reality of experience and the construction of historical knowledge. Historicism is overcome by means of its radical ... selfapplication; but really, it falls into a void, and nobody gains anything" (582).

Not everyone agreed with Troeltsch. Using Simmel's historical apriori as a premise, Max Scheler (1874-1928) influentially declared historicism self-undermining (1926/1960: 135-158). The historicist claims the historical record to show that epistemic and moral standards vary between cultures and epochs. In so doing, the historicist "naïvely" assumes there to be "historical facts". This is naïve since historicist reflection itself maintains that historical facts are "relative to the present". Historicism has thereby robbed itself of the data which could provide it with empirical support. Historicism refutes itself.

What did Simmel himself think of relativism and historicsm as philosophical positions? How did he interpret the historical apriori? Did he agree with Troeltsch that his position was a radical relativism?

To begin with the historical apriori, Simmel did not hold that all perspectives are equally good. For instance, while he is adament that some aspects of historical actors' experiences might never be understood, he does not draw the relativistic conclusion that therefore historical sources are infinitely plyable (1892/1989: 326). He adds that when historians investigate the experiences of past groups - rather than past individuals - their chances of getting at the original sentiments are high. This is because groups have "general, big and coarse interests" (331) that do not much change over time. Simmel also leaves room for the historian "genius" who is able to grasp past experiences to a higher degree 
than anyone else. The genius does so on the basis of "innate memories of the species" (328). Moreover, Simmel writes that "we are able to reconstruct the psychological processes of others and with a strong feeling of being totally correct ..." (328); or that "there is enough evidence" for the "monistic belief" that thought is largely "uniform and simple" (337). Simmel is somewhat less optimistic when it comes to historical laws or philosophies of history. Here there is little chance to overcome or adjudicate competing proposals. Simmel weakens the relativism of these claims, however, by declaring historical laws and philosophies of history to be of merely heuristic value (421): as guides for research they do not postulate conflicting truths.

As far as relativism in the Philosophie des Geldes is at issue, we need to attend primarily to the "relativity" point: the modern understanding of money corresponds to a diverse set of philosophical "relativisms". To begin with epistemic justification, Simmel holds that it is relative to epistemic principles. And since these principles need to be justified in turn, we end up in an infinite or circular chain. Simmel actually insists that the chain is both infinite and circular at the same time. It is infinite insofar as we are unable to reach absolute principles as ultimate stopping points. It is circular insofar as our justifying activity is never able to step beyond the circle of beliefs (1900/2004: 101-103). ${ }^{3}$ Somewhat abruptly Simmel adds an evolutionary epistemology according to which a representation is justified if, and only if, it has been produced by a psychological mechanism which adds to the fitness of the species. None of the "worldviews" of different species "copy" the external world "in its objectivity". They all have their own truth (ibid.: 104).

Simmel's ontological relativism relates to the distinction between Medieval and Modern ways of thinking: the ontology of substances has given way to an ontology of (quantitative) relations. There is no fact of the matter as to which ontology is absolutely correct. Still, the thought of "the general relativity of the world" is the natural "adjustment on the part of our intellect" to contemporary "social and subjective life in which money has found its real effective embodiment and the reflected symbol of its forms and movements" (ibid.: 518). This line of reasoning makes Simmel a historicist relativist about the conflict between (ontological) absolutism and relativism.

Finally there is philosophical "relativism" concerning opposites like "pluralism" and "monism", "realism" and "idealism", "subjectivism" and "objectivism": Simmel treats them all as "heuristic principles". "Objective truth" results from the interplay of many different such principles (ibid.: 112).

\footnotetext{
${ }^{3}$ Simmel took these distinctions from Spencer (1867).
} 
Was all this relativism by the standards of the time? Here one key litmus test was - as the Neokantians or Phenomenologists were urging - whether the given theory conflated "Genese und Geltung" (causal origin and validity). Simmel declared himself "not guilty". He emphasizes that the Law of Gravity "belongs within the category of the valid and meaningful that is not open to further [psychological or sociological] analysis" (1892/1989: 105). And elsewhere he sharply distinguishes between "positive ethics" (i.e. the sociology and psychology of ethics) and "prescriptive ethics" (1892-93/1989: 10-11). Max Adler (1919: 10) reports that "usually by relativism one means a state of mind which denies the possibility of universally valid claims and which reduces the validity of our judgments ultimately to their practical usefulness ..." Adler insists that "nothing of all this fits Simmel's intellectual dispositions". Max Frischeisen-Köhler (1920) also suggests that "relativism" cannot be used to characterize Simmel's position. His reason is that relativism has become "too general and vague" a term for it to be useful as a characterization of any philosopher. Still, judged by Edmund Husserl's (1859-1938) attack on "psychologism", every form of evolutionary epistemology is "psychologistic" (i.e. species relativism) (1900/1970: §36). Thus by Husserl's criteria Simmel's evolutionary epistemology is relativistic.

Are Simmel's relativisms relativistic by our standards today? It seems right to say that by most standards Simmel would at least qualify as an ontological relativist. Which ontological theory we accept depends on the culture we live in, and there is no higher court of appeal. As far as epistemic relativism is concerned, the issue is difficult to decide. Simmel's insistence on infinite chains of justification, or his evolutionary speculations would not be counted as obviously relativistic by most of today's epistemologists. His references to the circle of beliefs sound like a form of coherence theory. And it is an open debate whether and to what extent the coherence theory of epistemic justification has relativistic leanings (Steizinger 2015).

Summa summarum: It is hard to capture Simmel's enthusiastic search for ever new forms of relativism in today's categories and classifications. While one can recognize certain familiar relativistic motifs, the overall position remains elusive.

\section{Mannheim on Conservatism}

Turning from Simmel to Mannheim, the first central text for my concerns is his Habilitationschrift "Altkonservatismus" (1925/1986). This is a study of four legal philosophers and jurists in the early eighteenth century: Justus Möser (1720-1794), Adam Heinrich Müller (1779-1829), Gustav von Hugo (1764-1844), and Friedrich Carl von Savigny 
(1779-1861). As Mannheim explains, they formulated conservatism as a new "thoughtstyle", opposed to the "bourgeois-revolutionary style, the natural-law mode of thinking" (102). A thought-style is motivated by social-political interests and "constitutes a world" by means of its own specific vocabulary $(51,56)$. Conservatism can, but need not, combine with romanticism. Romanticism arises in opposition to a "thorough-going rationalisation of the world". It is motived by the "displaced" and "irrational" $(59,65,66)$. Political conservatism is an "objective", "historical-dynamic structural complex" (75). It presupposes a "society differentiated into classes" (86).

One of Mannheim's central aims is to develop a "morphology of conservative thought", and to identify its "inner formative principle" (87). By Mannheim's reckoning this principle is the clinging to the concrete. For instance, property (in Möser) is a "definite, vital, and reciprocal relationship between the owner and the thing owned" (89). Freedom must be concrete not abstract; it must be tied to our "individual laws". Ranke later insisted that freedom must tied to estates or the state (93).

Mannheim holds that the conservative thought-style can only be understood as the negation of the earlier "natural-law thought-style". The latter was understood by conservatives as having the following ingredients (106-107):

(A) Doctrines of ...

the state of nature the social contract popular sovereignty

Rights of Man
(B) Thinking

\author{
rationalism \\ eduction from principles \\ universal principles \\ universal applicability of all laws \\ atomism and mechanism \\ static thinking
}

The conservative response took the form of insisting that social organisms are unique; this precluded universal principles or universal laws (108). It also favoured totalities (cultures, traditions) over individuals. And against "reason" it stressed the importance of "history, life, nation" (107), and celebrated the "irrationality of reality" (108). To be precise, it was only the first generation of conservatives that attacked reason outright. Later generations - esp. Hegel - aimed to fuse history and rationality by developing dynamic conceptions of reason (109). 
Abstract morphology to one side, Mannheim also seeks to illuminate the actual historical development. The "first conservative position" (in Möser) was a reaction of the Prussian nobility and its middle-class "ideologues" against "bureaucratic-absolutist rationalism" (112-114). The ideologues were "socially unattached intellectuals" who "hired out their pens"; they were "archetypal apologists". (116-119). Importantly, (philosophy of) history now became a key focus. For Mannheim this is "the positive element" (118) in conservatism. Möser emphasized old customs and habits; every town should have its own laws (134). Historicism emerged once the interest in history became pronounced. "Historicism is ... of conservative origin," Mannheim wrote. He explaines that we reach historicism "when the process whereby things have come about is itself experienced with feeling" (127). In this context Mannheim applauds "... the fruitful relativism flowing out of historicism ... which renders even the observer relative to the process of becoming which moves over and through him" (126). Mannheim adds: "This form of thinking ... has in effect become a historical a priori for us" (143).

Müller is the central figure in the second stage the development. He began to combine conservatism with romanticism. Romanticism means an emphasis on life and its diversity. For Mannheim this move anticipated "Lebensphilosophie" (136-138). Müller was generally sceptical about conceptual thought. No concept was able to capture the dynamic nature of social realities (141). Müller aimed to make thinking similar to life: this meant an extensive use of analogy and conceiving of the world as unfolding according to diametrically opposed principles (143).

The third phase brought a consolidation of the conservative thought-style. This was the time of the "Historical School" and von Savigny. The latter never tired of attacking the idea of general (Napoleonic) legal codes: "the real seat of law is the common consciousness of the people" (156). As a romantic conservative von Savigny discovered irrationality everywhere, including in the individual and in the application of laws (166-167). Mannheim deems von Savigny important as a forerunner of the humanities of his (i.e. Mannheim's) time: von Savigny developed the method of "elucidation" (studying phenomena in and through their historical becoming) that informed all later work in the humanities (184).

A second important figure in the third stage of the development was von Hugo. He took "... a preliminary step towards the fruitful relativism of historicism" by developing a "unique relativism" tied to "disillusioned conservatism" (176). Von Hugo undermined natural law by measuring it against the plurality of positive law; but he also criticized positive law in light of natural law. Neither perspectives was ultimately privileged. von Hugo strikes Mannheim as a forerunner of Max Weber (176). 


\section{Mannheim on Historicism and Relativism}

Historicism and relativism surface at many points in the Habilitationsschrift, and it is useful to pull together the main themes and influences. First, historicism, relativism, and elucidation are said to be "positive elements", a valuable legacy, of political conservatism; a "historical a priori for us". Second, from Oswald Spengler's (1880-1936) Untergang des Abendlandes (1918/1991), Mannheim adopts the idea of a "morphology" of "thoughtstyles", and of "formative principles" that "constitute" their respective "worlds" and incommensurable languages. Third, Altkonservatismus endorses Simmel's conception of the historical apriori: Enlightenment and conservative writing of history are said to have been differrent; and at least by implication historical worlds must be worlds-for-differentthought-styles. Finally, fourth, Mannheim does not allow for a neutral viewpoint. The fact that intellectuals were "socially unattached" did not enable them to achieve such neutrality; instead they were forced to "hire out their pens".

In the paper "Historismus" (1924/1964) - written just one year before the Habilitationsschrift was presented in Heidelberg, Mannheim draws a somewhat different picture of historicism and relativism. One central motif is the distinction between three different fields of knowledge and their respective histories (294). These fields differ in the extent to which they are affected by historicism.

(i) "Civilisation": this is the realm of the natural sciences and mathematics, of "static truths" and progress (282). In this arena, and only here, the rationalist epistemologies of Neokantianism and Phenomenology have traction. These sciences are not affected by historicism.

(ii) "Dialectic Rationality": This is the domain of philosophy to which historicism applies. Here truth is "dynamic", and can only be captured by Hegelian dialectic. At best, philosophical systems "express the truth of their respective epochs" (287). But Mannheim also speaks of "dialectical truth" as the truth concerning the dynamics and telos of history (289).

(iii) "Soul-culture": This is where the historical-cultural sciences belong. They are committed to the idea that "every epoch must be interpreted through its very own soulcentre" (292). This is in line with historicism or relativism. But still, Mannheim deems it possible to offer a criterion of truth for this arena, too: it is to grasp the object "adequately in its full depth" (293). 
A second central motif of the 1924 paper relates to the "historical apriori". Why do we assume that our perspectives are able to adequately capture the "historical Dinge-an-sich"? Mannheim thinks that "Troeltsch found the right starting point" for an answer (276). Mannheim is referring here to Troeltsch's cryptic remark that "thought must ... have a secret link to reality" (Troeltsch 1922/1977: 183): historians' perspectives are often adequate to their subject matter since both the perspectives and the subject matter are products of one and the same historical process. Mannheim expresses the thought also in idealist garb: “... principally the absolute ... can be grasped only ... in categories that are shaped by [its own] process of becoming"; "history gives us concrete-contentful standards; ... we are able to identify them only because we already have them instinctively, insofar as we are carried by the total spirit ..." (1924/1964: 303-305)

For Mannheim the two central motifs - the distinction between (i), (ii), (iii) and the development of the absolute spirit - are connected. The absolute spirit has been invested in the three forms of knowledge to different degrees in different epochs. Mannheim also suggests that different social classes are preferentially drawn to one of the realms. But no class carries the "total movement" (296). Although Mannheim admits that his own philosophy is also "tied to a standpoint", he still deems himself capable of predicting the next step, beyond (iii). This next step is the challenge to find a perspective from which the tripartite distinction of fields of knowledge (i) to (iii) can be overcome.

This "pluralist" (304) theoretical edifice, Mannheim believes, can be used to block the charge of relativism. Different perspectives can reach partial truths - insofar as the absolute grants these. Different truths of different historical periods are not different interpretations of the same, but interpretations of different stages of the absolute or spirit. This is not to say that perspectives cannot be criticized. But the main criticism that can be directed at them is that they overgeneralize: they claim to apply to a much wider range of phenomena than they actually do (253).

In Mannheim's Ideologie und Utopie (1931/1936) we get yet a third response to historicism and relativism. Mannheim now seeks to adapt Marxist vocabularies and motifs, especially elements of Georg Lukacs' Geschichte and Klassenbewusstsein (1923/2000). "Thought-styles" are replaced with "ideologies" qua holistic systems of meaning and beliefs (1931/1936: 74). Mannheim now also puts a much greater emphasis on the "Seinsgebundenheit" of thought. That is, the knowledge of politics, the humanities and the social sciences are all tied to material conditions (243-44). But Mannheim is convinced that the thesis of the Seinsgebundenheit of knowledge does not commit him to relativism. Mannheim prefers to call his view "relationism": "all historical knowledge is relational 
knowledge". In other words, different bodies of knowledge are always tied to different webs of meaning and beliefs, and to specific historical situations. This is why a strict division between Genese and Geltung cannot be upheld (76). Of course, by the Neokantian standards, denying such strict division was precisely what qualified Mannheim's position as relativist.

Nevertheless, there is a criterion for assessing ideologies or theories, Mannheim claims. A given ideology or theory is correct if it does not "prevent man from adjusting himself at the given historical stage" (85). Finally, Mannheim needs an epistemic subject for identifying the specific Seinsgebundenheit of specific ideologies and for creating "syntheses" out of them. He resurrects a key figure from his Altkonservatismus study (and Weber [1923]): the "socially unattached (freischwebende) intelligentsia". Its epistemic privilege rests on its ability to replace class-ties with "Bildung" ties (1931/1936: 138).

Turning from Mannheim's views to their reception, in the late 1920s and early 1930s Mannheim's views triggered what in retrospect we might call the "Sociologism Wars". Since I have analysed these debates at greater length elsewhere (Kusch 1999), and since I return to them below, suffice it to say that Mannheim's position was attacked from every end of the political spectrum. Key points of contention were the restriction of Seinsgebundenheit to the social sciences and the humanities (Sombart); an excessive or insufficient proximity to Marx (A. Weber, Neurath); the inflationary use of "ideology" (Jonas, Stern, Tillich); the Hegelianism of the Historismus paper (Horkheimer); and - of course - Mannheim's alleged relativism (Grünwald). (Kusch 1999)

Which naturally brings us to the question whether Mannheim is a relativist by today's standards. This is best answered separately for the three key texts. It is hard to see how one could read the Altkonservatismus study as anything but a relativistic investigation. The extensive use of Spenglerian categories and ideas commits Mannheim to a form of cultural relativism based on incommensurable thought-styles. The account of the Historismus paper avoids relativism, but at the high price of a Hegelian metaphysics. Finally, the position of Ideologie und Utopie escapes the relativism-charge only by relying on the assumption of the "free-floating intelligentsia".

\section{Interpretation and Evaluations}

I now turn to some evaluative comments, using existing criticism as my starting points. I begin with problems in Simmel's case study of money and philosophy. 
The first issue to be assessed is Simmel's relativistic methodology. Contemporary critics found it unconvincing. For Emile Durkheim (1858-1917) Simmel is wrong to isolate various forms and conceptions of money from the institutions that make them possible (1902/1980: 98). Durkheim also condemns Simmel's "bastard speculation" as a mixture of scientific observation and artistic intuition" (ibid.). Max Weber (1864-1920), both in his Die protestantische Ethik und der Geist des Kapitalismus (1904-5/1976) and in a 1908manuscript (1908/1970), is also critical. In the book he rejects the way in which Simmel detaches modern money from the capitalist mode of production (1904-5/1976: 193, 185). In the manuscript Weber reports that the money-book triggers "out-right explosions of rage" amongst economists (1908/1970: 161). Weber sees the main culprit in Simmel's undisciplined use of analogy (ibid.: 160). It is hard to disagree.

Perhaps there is a way, however, to redeem Simmel's Philosophie des Geldes. Remember that Simmel took the book to be a contribution to the philosophy of history and that for him philosophies of history are not strictly true or false. Their value is to be measured by how useful they are as heuristic tools, that is, as temporary signposts for empirical work, and as ultimately and ideally fully superseded by the latter. Taken in that sense, we might think of Simmel as urging sociologists to determine the ways in which economic theorizing and financial practices have influenced philosophical thought. Treating Simmel's book in this way is to treat it the way we nowadays think of other such sweeping theses, for instance, the "Sombart Thesis" (Sombart 1902) according to which double bookkeeping brought about the Scientific Revolution; the "Weber Thesis" (Weber 1904-5) on the interaction between Protestantism and capitalism; or the "Merton Thesis" (Merton 1938) on Pietism and early experimental science. These sweeping theses are overgeneralizations and false as such. But they are highly suggestive of more restricted and local case studies (e.g. on the influence of game-theory in political philosophy).

As far as Simmel's more general comments on relativism and historicism are concerned, the early responses were either highly critical or excessively charitable. I have already quoted Troeltsch's dismissive assessment above (1922/1977: 582). More sympathetic commentators like Adler (1919) or Frischeisen-Köhler (1920) confirm that Troeltsch's assessment was typical of the times. Curiously, Adler and Frischeisen-Köhler then go on to defend Simmel against the charge of relativism by rendering the doctrine in ways Simmel himself would have rejected: Simmel does not (like Frischeisen-Köhler) take relativism to be undefinable; and he does not (like Adler) conceive of relativism as a reduction of truth to utility. 
The debate over Simmel's relativism has not ended in the 1920s. Raymond Bourdon (1989) suggests that Simmel is a anti-skeptical "neokantian relativist" seeking to identify "variable apriori assumptions" (1989: 415). Bourdon's interpretation belongs to a French tradition of reading Simmel that Gregor Fitzi (2002) traces back to the early twentieth century. On this interpretation Simmel's relativism is a "transcendental philosophy aware of its limits in both epistemology and ethics" (2002: 247). One need not disagree with this suggestion to feel that it gets at only some aspects of Simmel's overall relativist aspirations. For instance, it has nothing to say about Simmel's ontological relativism.

Commentators from the realm of cultural studies have highlighted other aspects of Simmel's position. Deena and Michael A. Weinstein celebrate Simmel's "historicism" or "postmodern form of historizing" as "a kind of radical pragmatism ... History is the freedom of the historian to historize according to any interest in the past ... so long as the control of fact is respected" (1993: 183). Elizabeth S. Goodstein $(2017: 86,160)$ holds that "Simmel deployed epistemic relativism ... as a means of overcoming what appear to be aporetic dualisms - between materialism and idealism, determination and freedom, life and form ..." Goldstein believes that even the opposition between relativism and absolutism is overcome where Simmel's "relativized relativism" historicizes both. Goodstein's remark is indeed a helpful observation.

Finally, Klaus Christian Köhnke (1995: 480) and Wilfried Geßner (2003: 92-3) suggest that Simmel's relativism is really a form of Mannheimian "relationism". The reason, according to Geßner, is that Simmel's intentions are antiskeptical and aiming to "combine the objectivity of validity with the relativity of origin". Unfortunately, neither author then goes on to defend the coherence and plausibility of Mannheim's relationism.

As I already indicated in the last section, Mannheim's attempt to steer a path between relativism and absolutism did not meet with much enthusiasm in the 1920s. Max Horkheimer insisted that Mannheim should have followed Marx on this point. Whereas Marx had taken the view that all knowledge was relative to class, Mannheim was trying to re-introduce an absolutistic perspective. For Mannheim all particular viewpoints ultimately seemed to fit together into one big absolute viewpoint (Horkheimer 1929/1982: 486).

Ernst Grünwald chose a different line of attack. Grünwald accused Mannheim's sociology of knowledge of being both "absurd" and "false". The charge of absurdity is justified as follows: "'Relationism' claims that all thinking is valid only relative to a standpoint; but for this very sentence, that is, that all thinking is valid only relatively, relationism demands absolute validity" (1934/1982: 750). But Mannheim's 'sociologism' is also based on the altogether false assumption that thinking in general, and judgements in 
particular are seinsgebunden. According to Grünwald this has to be false: since judgements can be studied from many different viewpoints-e.g. those of sociology or psychologyjudgements in themselves cannot be reduced to any of these viewpoints (1934/1982: 707). Finally, Grünwald argues that the sociology of knowledge could never replace epistemology and that research in the sociology of knowledge would always have to presuppose prior epistemological research. Epistemology studies the validity claims of judgements, and these validity claims are independent of, and prior to, external factors like social interests (1934/1982: 701-707). - Mannheim did not have the argumentative resources needed to rebut these attacks.

There are also important and weighty objections to Mannheim's Altkonservatismus study. It is easy, for example, to agree with Rodney Nelson (1992) that there is "a relative paucity of social-historical analysis in Conservatism; [and that] a demographic portrait of the German aristocracy in the early nineteenth century and a rigorous documentation of shifts in their socioeconomic status would have added greatly to the analysis" (1992: 43). Relatedly, Nelson also laments the "static essentialism of thought-styles" and the idea that "cultural products actually contain entelechies; that the development of a style of thought is in some indeterminable sense prefigured in its origin" (1992: 45). Other critics have attacked the tautology in Mannheim's imputation of thought-styles to groups: Mannheim defines groups in terms of thought-styles, and thought-styles in terms of groups (Carlsnaess 1981). On a more general level, later-day sociologists of knowledge have lamented Mannheim's excluding of mathematics and the natural sciences from the subject matter of their discipline (Bloor 1973; cf. Seidel 2011).

And yet, all these important criticisms do not invalidate the attempt to define political conservatism; and Mannheim's definition remains influential even today. Moreover, the essential core of Mannheim's sociohistorical study of philosophical knowledge can easily be formulated without any "morphology of thought-styles." As an exercise in the sociology of philosophy - showing how historicism and relativism first emerge in political conservatism - Mannheim's Conservatism remains a model and inspiration.

Turning to the broader issue of how to think about historicism and relativism I want to underline for a last time the interesting historical reflexivity in both account. Both Simmel and Mannheim seek to understand the historical conditions of the possibility of their own analyses - and this for both historicism and relativism. This type of historical reflexivity is a rare commodity in contemporary sociology of philosophical (or scientific) knowledge.

Moreover, Simmel's contribution to historicism is still thought-provoking and wellworth reflecting on. That historical facts are not simply given is now widely taken for 
granted; and today we have of course authors like Hayden White (1973) and lan Hacking (1995) who put forward more radical historiographical claims. Of course philosophers today do not believe that historical reflexivity invariably leads into an abyss - like Troeltsch did; nor that it can justify universal values - like Scheler did. But we still struggle with explaining how historical reflexivity and historical realism are to be reconciled. In that sense Simmel's challenge is still pressing today.

Finally, as far as Simmel's celebration of relativism is concerned, it is a bit unfortunate that he runs together so many different ideas together under this one title. Many of the things Simmel called "relativism" are today flourishing research projects in their own right (evolutionary epistemology, pluralism, coherence theories, infinitism, etc.).

Turning from Simmel to Mannheim, the latter's contortions to escape the charge of relativism are hardly convincing since in each of his programmes the intellectual costs are too high. Spenglerism with its ingredients of incommensurability, skepticism and organicism is not an attractive option. The Hegelianism of the Historismus paper avoids epistemic relativism only at the cost of ontological relativism (the absolute presents different periods with different realities). Concerning the free-floating intelligentsia, it is puzzling how Mannheim by 1931 could suddenly convince himself that it is able, after all, to escape "the fate" so vividly described in Altkonservatismus.

\section{Summary and Conclusions}

I have tried to show Simmel's and Mannheim's deep and extensive preoccupations with relativistic and historicist themes. Both philosopher-sociologists thought of relativism and historicism as important elements of their methodology for the sociology of philosophy; both tried to understand the emergence of relativism and historicism historically; and both reflected systematically on which forms of relativism might be defensible. Many of their central questions and concerns have stood the test of time.

There are also of course important differences between Simmel and Mannheim. On the one hand, as we move historically forward, from Simmel to Mannheim, the sociology of knowledge sheds a commitment to broad-brush and speculative philosophy of history, at least as far as the case-studies are concerned. This is progress. On the other hand, the early SImmel's theorizing concerning historicism seems more sober, more twenty-first-century than Mannheim's frequent relapses into Spenglerism or Hegelianism (at least in his programmatic texts). At the same time, in his theoretical writings Mannheim challenges us 
to investigate how epistemology must change to do justice to the results of the sociology of knowledge. To me the question is still relevant.

Where does all of this leave us concerning the issue of relativism, especially relativism in the context of the sociology of knowledge? The question is worth asking in this general form, since clearly the issue is as topical today as it was a hundred years ago (cf. Schantz and Seidel 2011). Obviously, we cannot simply adopt 'the right answer' from Simmel and Mannheim; as we have seen, their proposals are beset by many problems. But perhaps the real lesson is in any case an indirect one: perhaps the connection between a philosophically worked-out commitment to relativism on the one hand, and historical case studies in the sociology of knowledge on the other hand is not as tight as is often assumed by cardcarrying sociological relativists. Simmel declared himself a relativist but it remained unclear what precisely his relativism amounted to. And yet he gave us a highly suggestive and thought-provoking investigation into the influence of (theorizing about) money on our modern worldview. Mannheim had a clearer view of what relativism was but thought of it as something the sociology of knowledge had to avoid at all costs. His attempts to do so failed. But this failure had no direct negative consequences for his brilliant historical work. Fortunately, in neither case did the alck of success regarding the philosophical handling of relativism weaken the quality and interest of the sociological-historical case studies.

\section{Literature}

Adler, M. (1919),Georg Simmels Bedeutung für die Geistesgeschichte, Leipzig: Anzengruber.

Bloor, D. (1973), "Wittgenstein and Mannheim on the Sociology of Mathematics", Studies in History and Philosophy of Science 4: 173-191.

Bourdon, R. (1989), “Die Erkenntnistheorie in Simmels 'Philosophie des Geldes'”, Zeitschrift für Soziologie 18: 413-425.

Carlsnaess, W. (1981), The Concept of Ideology and Political Analysis, Westport: Greenwood Press.

Fitzi, G. (2002), Soziale Erfahrung und Lebensphilosophie: Georg Simmels Beziehung zu Henri Bergson, Konstanz: UVK Verlagsgesellschaft. 
Frischeisen-Köhler, M. (1920), “Georg-Simmel”, Kantstudien 24: 1-51.

Geßner, W. (2003), Der Schatz im Acker: Georg Simmels Philosophie der Kultur, Weilerswist: Velbrück.

Goodstein, E. S. (2017), Georg Simmel and the Disciplinary Imaginary, Stanford, Cal.: Stanford University Press.

Grünwald, E. (1934/1982), "Systematische Analyse der wissenssoziologischen Theorien", in Meja and Stehr (1982), 681-747. (First published in 1934.)

Hacking, I. (1995), Rewriting the Soul: Multiple Personality Disorder and the Sciences of Memory, Princeton, N.J.: Princeton University Press.

Horkheimer, M. (1930/1982), "Ein neuer Ideologiebegriff", in Meja and Stehr (1982), 47496. (First published in 1930.)

Husserl, E. (1900/1970), Logical Investigations, London: Routledge \& Kegan Paul. (The German original was published in 1900.)

Kusch, M. (1999), "Philosophy and the Sociology of Knowledge", Studies in History and Philosophy of Science 30A: 651-86.

Köhnke, K. C. (1995), Der junge Simmel in Theoriebeziehungen und sozialen Bewegungen, Frankfurt am Main: Suhrkamp.

Lessing, T. (1921/2012), Geschichte als Sinngebung des Sinnlosen, Bremen: DOGMA. (The German original was published in 1921.)

Lukacs, G. (1923/2000), History and Class Consciousness: Studies in Marxist Dialectics, Cambridge, Massachusetts: The MIT Press. (The German original was published in 1923.)

Mannheim, K. (1924/1964), "Historismus", in Mannheim, Wissenssoziologie: Auswahl aus dem Werk, Berlin: Luchterhand, 246-307. (The German original was published in 1924.) 
Mannheim, K. (1925/1986), Conservatism: A Contribution to the Sociology of Knowledge, London: Routledge. (The German original was published in 1925.)

Mannheim, K. (1931/1936), Ideology and Utopia, London: Routledge \& Kegan Paul. (The German original was published in 1931.)

Merton, R. K. (1938), "Science, Technology and Society in Seventeenth-Century England", Osiris 4: 360-632.

Meja, V. and N. Stehr (eds.) (1982), Der Streit um die Wissenssoziologie, 2 vols., Frankfurt am Main: Suhrkamp.

Nelson, R. D. (1992), "The Sociology of Styles of Thought", The British Journal of Sociology, Vol. 43: 25-54.

Schantz, R. and M. Seidel (eds.) (2011), The Problem of Relativism in the Sociology of (Scientific) Knowledge, Frankfurt am Main: Suhrkamp.

Scheler, M. (1926/1960) Die Wissensformen und die Gesellschaft, Bern und München: Francke. (The German original was published in 1926.)

Seidel, M. (2011), “Karl Mannheim, Relativism and Knowledge in the Natural Sciences - A Deviant Interpretation", in Schantz and Seidel (2011), 183-214.

Simmel, G. (1892/1989), "Die Probleme der Geschichtsphilosophie”, in Simmel, Gesamtausgabe, vol. 2, Frankfurt am Main: Suhrkamp, 297-421. (The German original was published in 1892.)

Simmel, G. (1892-3/1989), Einleitung in die Moralwissenschaft, in Simmel, Gesamtausgabe, vol. 3, Frankfurt am Main: Suhrkamp. (The German original was published in 1892-3.)

Simmel, G. (1900/2004), The Philosophy of Money, London: Routledge. (The German original was published in 1900.) 
Simmel, G. (2005), Briefe 1912-1918, Jugendbriefe, in Simmel, Gesamtausgabe, vo. 23, Frankfurt am Main: Suhrkamp.

Sombart, W. (1902), Der moderne Kapitalismus, Berlin: Duncker \& Humblot.

Spengler, O. (1918/1991), The Decline of the West, New York: Oxford University Press.

Spencer, H. (1867), First Principles, London: Williams and Norgate.

Steizinger, J. (2015), “In Defence of Epistemic Relativism: The Concept of Truth in Georg Simmel's Philosophy of Money", in C. Kanzian, J. Mitterer, K. Neges (eds.) (2015), Realism Relativism - Constructivism, Kirchberg am Wechsel: Austrian Ludwig Wittgenstein Society, 300-302.

Troeltsch, E. (1922/1977), Der Historismus und seine Probleme, in Troeltsch, Gesammelte Schriften, vol. 3, Aalen: Scientia Verlag.

Weber, A. (1923), Die Not der geistigen Arbeiter, München, Leipzig: Duncker \& Humblot.

Weber, M. (1904-5/1930), The Protestant Ethic and the Spirit of Capitalism, London and Boston: Unwin Hyman.

Weber, M. (1908/1970), “Georg Simmel as Sociologist”, Social Research 39: 155-163.

Weinstein, D. and M. A. Weinstein (1993), Postmodern(ized) Simmel, London and New York: Routledge. 